\title{
Antioxidant activity of Maytenus imbricata Mart., Celastraceae
}

\author{
Grácia D. F. Silva, , ${ }^{* 1}$ Silvia R. S. Silva, ${ }^{1}$ Luiz C. A. Barbosa, ${ }^{2}$ Lucienir P. Duarte, ${ }^{1}$ Sonia M. \\ R. Ribeiro, ${ }^{3}$ José H. Queiroz, ${ }^{3}$ Sidney A. Vieira Filho, ${ }^{1}$ Márcio L. R. Oliveira ${ }^{4}$
}

\author{
${ }^{1}$ NEPLAM, Departamento de Química, ICEx, Universidade Federal de Minas Gerais, Avenida Presidente Antônio \\ Carlos, 6627, Pampulha, 31270-901 Belo Horizonte-MG, Brazil, \\ ${ }^{2} L A S A$, Departamento de Química, CCE, Universidade Federal de Viçosa, Avenida PH Rolfs, s/n, Campus UFV; \\ 36570-000 Viçosa-MG, Brazil, \\ ${ }^{3}$ Departamento de Bioquímica, Universidade Federal de Viçosa, 36570-000 Viçosa-MG, Brazil \\ ${ }^{4}$ Departamento de Engenharia Florestal, Universidade Federal de Viçosa, 36570-000 Viçosa-MG, Brazil
}

\begin{abstract}
RESUMO: "Atividade antioxidante de Maytenus imbricata Mart., Celastraceae". A atividade antioxidante, poder redutor (RP) e a atividade coletora de radicais livres (FRS) usando 2,2-difenil1-picrilhidrazil (DPPH), e a concentração de substâncias fenólicas totais dos extratos e substâncias isoladas das folhas, caules e raízes de Maytenus imbricata Mart. (Celastraceae) foram avaliados. Alguns extratos, a mistura de compostos fenólicos e epicatequina mostraram alto poder redutor e atividade antioxidante (DPPH) em comparação com o padrão butilhidroxianisol (BHA) e ácido gálhico (GA) utilizados no ensaio. O extrato acetato de etila das folhas mosraram alto teor de substâncias fenólicas e alto poder redutor e atividade antioxidante em relação aos outros extratos. Este fato indica haver alguma relação entre a concentração de substâncias fenólicas e o poder redutor. O solvente usado no processo de extração influencia a composição química dos extratos e, consequentemente, as atividades redutoras e antioxidantes.
\end{abstract}

Unitermos: Atividade antioxidante, poder redutor, Maytenus imbricata, Celastraceae.

\begin{abstract}
The free radical scavenging activity (FRS) using 2,2-diphenyl-1-picrylhydrazyl (DPPH), the reducer power and the total phenolic concentration of extracts and compounds isolated from leaves, branches and roots of Maytenus imbricata Mart. (Celastraceae) were evaluated. Some extracts, a mixture of phenolic compounds (MPC) and epicatechin showed higher RP and FRS (DPPH) activities in comparison with the standard butylhydroxyanisole (BHA) and galic acid (GA) used in assays. The ethyl acetate extract from leaves showed higher total phenolic content and also higher RP and FRS (DPPH) than the other extracts. These facts indicate that there are some relations between phenolic concentration in the extract and the antioxidant activity and the reducer power. The solvent used in the extraction process influences the chemical composition of the extracts and consequently its antioxidant and reducer power activities.
\end{abstract}

Keywords: Antioxidant activity, reducer power, Maytenus imbricata, Celastraceae.

\section{INTRODUCTION}

Free radicals are responsible by lipid peroxydation occurred during production and storage of nutrients (Singh et al., 2002) and are directly involved in some cancers, cardiovascular disorders, diabetes (Yildrin et al., 2001), Alzheimer's disease (Allison et al., 2001), atherosclerosis and others human pathologies. In animal organism, different biochemical routes of the normal metabolism involve free radicals formation, but in these cases defense mechanism processes against the oxidative process propagation are also involved. However, these mechanisms do not show a good and constant efficacy (Yildrin et al., 2001). So, exogenous antioxidant compounds acts as an auxiliary function in this defense processes. Antioxidants block the free radicals formation by different ways and establish important control function in some oxidative stress diseases (Allison et al., 2001, Harbone, 1994) and in food conservation (Skerget et al, 2005). Then, new natural antioxidants, mainly those isolated from medicinal plants, acquire great pharmacological importance and the researches of this compounds have been developed too much in the last years (Capecka et al., 2005; Harish \& Shivanandappa, 2006; Wu et al., 2006; Andrade et al., 2007; Castilhos et al., 2007; Souza et al., 2007; Vicentino \& Menezes, 2007; Balestrin et al., 2008; Iha et al., 2008; Nunes et al., 2008; Fonseca et al., 2009; Krishnamoorthy et al., 2009; Morais et al., 2009; Rebelo et al., 2009).

Maytenus imbricata Mart. ex. Reissek (Celastraceae) is a sub shrub or a tree, with about 3 $\mathrm{m}$ height. It is endemically encountered in "campo rupestre" (Rupiculous field grasslands) regions mainly in 
Bahia and Minas Gerais States of Brazil (Okano, 1992). Antiulcerogenic and analgesic effects (Queiroga et al., 2000; Gonzalez et al., 2001; Santos et al., 2007; Mota et al., 2008), antitumoral (Pullen et al., 2003; Ravelo et al., 2004), antimicrobial activity (Orabi et al., 2001; Estevam et al., 2009), antispasmodic (El Tahir et al., 1999), insecticidal (Avilla et al., 2000), citotoxic (Spivey et al., 2002), neuroleptic and anticonvulsant properties (Sousa \& Almeida, 2005; Quintans-Júnior et al., 2008), antiinflammatory (Jorge et al., 2004; Santos et al., 2007; ), antiespermatogenic (Montanari et al., 1998) and antidiabetical properties (Okine et al., 2005) are pharmacological activities attributed to different species of Maytenus.

Through phytochemical methodologies was possible to isolate different lupanic triterpenes from stems and branches hexane extracts of M. imbricata (Silva et al., 2005). Giving sequence in our studies of $M$. imbricata, in the present work were determined the total phenolic content; free radical scavenging (FRS) using 2,2-diphenyl1-picrylhydrazyl (DPPH) method, and the reducer power (RP) of different extracts from leaves and branches, and of hydro-alcoholic extract from roots. Were also tested a mixture of phenolic compounds (MPC) and epicatechin (CTC), both isolated by fractioning of leaves extract of Maytenus imbricata.

\section{MATERIAL AND METHODS}

\section{General procedures}

FFolin-Ciocalteu reagent, 2,2-diphenyl-1picrylhydrazyl (DPPH), butylhydroxyanisole (BHA), galic acid (GA) and potassium ferricyanide (III) were purchased by Sigma Chemical Co. (USA) and analytical grade solvents from VETEC (Brazil). The ultraviolet analyses were carried out in a Shimatdzu UV-1601 and infrared (IR) analyses in a Perkin Elmer SPECTRUM 1000 spectrometer in the range of 500 a $4000 \mathrm{~cm}-1$, using $\mathrm{KBr}, 1 \%$ solution. Nuclear magnetic resonance (NMR) spectral data were obtained in a Brücker AVANCE DRX400 spectrometer.

\section{Plant material}

Samples of leaves, branches and roots of M. imbricata Mart. (Celastraceae) were collected in Camarinhas mountain area of Ouro Preto City, Minas Gerais State, Brazil, and a voucher specimen is deposited (No 27.780) at the Herbarium of the Botany Department, Universidade Federal de Viçosa (UFV), Minas Gerais Brazil.

\section{Extraction and isolation procedures}

The leaves of $M$. imbricata were dried at room temperature (r.t.), crushed in a mill and the material
(127.55 g) submitted to extraction in a Soxhlet apparatus with hexane, chloroform, ethyl acetate and finally with ethanol. After solvent removal in a rotatory evaporator the leaves hexane extract (LHE), chloroform extract (LChE), ethyl acetate extract (LEAcE) and ethanol extract (LEtE) were respectively obtained (Table 1). During hexane withdraw from LHE in a rotatory evaporator, a solid material formation was observed and carefully separated by filtration [LHES $(2.5 \mathrm{~g})]$. Similar process was also observed during ethanol withdraw from (LEtE) and, in this case the solid material was codified as DCT (0.97 g). The analyses by thin layer chromatography (TLC) and by gas chromatography coupled with mass spectrometry (GC-MS) indicated friedelin and $\beta$-friedelinol as the mainly constituents of LHE, pentacyclic triterpenes also encountered in other Maytenus species. By IR, ${ }^{1} \mathrm{H}$ and ${ }^{13} \mathrm{C}$ NMR spectral data was possible to identify DCT as dulcitol (galactitol), a polyol commonly encountered in different species of the Celastraceae family (Sousa et al., 1990).

The fractioning of the leaves ethyl acetate extract (LEAcE) (11.9 g) by silica gel column chromatography (CC) furnishes a solid material (CTC). By IR and ${ }^{1} \mathrm{H}$ and ${ }^{13} \mathrm{C}$ NMR spectrometry, including 2D-NMR experiments was possible to identify CTC as flavan-3-ol (epicatechin).

Branches were dried at r.t., crushed $(883.36 \mathrm{~g})$ and submitted to extraction in a percolator at r.t. with hexane, ethyl acetate and finally with ethanol. This processes furnished the hexane extract (BHE), ethyl acetate (BEAcE) and ethanol extract (BEtE). In the BHE preparation, a precipitation of a solid material was observed during hexane removal in a rotatory evaporator. The removal process was stopped; the solution cooled to r.t. and the solid was separated by single filtration. After dried in an Abderhalden apparatus this solid was codified as BHES $(8.29 \mathrm{~g})$. The analysis by TLC and GC-MS indicate that BHES were constituted mainly by lupane triterpenes (Silva et al., 2005). Similar precipitation process was observed during BEAcE preparation. The solid [MPC (2.28 g)] obtained was analyzed by IR spectrometry and submitted to $\mathrm{FeCl}_{3}$ test (Santos \& Mello, 2003). The results of these analyses indicated the presence of condensed tannins in MPC.

After dried at r.t. and crushed, the roots (107.12 g) were submitted to extraction with a mixture of ethanolwater (8:2). The solvent was removed in a rotatory evaporator producing the root ethanol-water extract REWE (7.8 g).

\section{Total phenolic}

The total phenolic content in extracts and compounds isolated from $M$. imbricata were determined in according to Folin-Ciocalteu method (Singh et al., 2002). All tests were realized in triplicate. 


\section{Free radical scavenging (FRS) activity}

FRS activity of samples was determined in according to method described in literature (Blois, 1958; Singh et al., 2002). Samples [50.0 and $100.0 \mu \mathrm{L}$ (50.0 and $100.0 \mathrm{ppm}$ ), in triplicate] of each M. imbricata extract or compound were submitted to this method. The results of FRS activity were expressed as inhibition percent, calculated through optical density (OD) using the following formula:

$\%$ FRS activity $=[\mathrm{OD}$ control $-(\mathrm{OD}$ sample $\mathrm{x}$ OD control $\left.\left.^{-1}\right)\right]$ x 100

\section{Reducer power (RP)}

The RP was evaluated in samples of extracts $(1.0 \mathrm{~mL}$ ) and compounds solutions (50.0 to $400.0 \mathrm{ppm}$ ) according to literature (Yildrin et al., 2001).

\section{Statistical analyses}

The statistical analyses of all triplicate assays were realized using ESTATISTICA software. Media, standard deviations and linear regression $\left(\mathrm{R}^{2}\right)$ had been determined. The differences between the samples were established by analyses of variance (ANOVA). The level of significance was determined at $\mathrm{P}<0.05$ for all experiments.

\section{RESULTS AND DISCUSSION}

Using Folin-Ciocateau reagent (Singh et al., 2002) was possible to identify the presence of phenolic compounds in the polar extracts obtained from leaves, branches and roots of $M$. imbricata. The results indicated a correlation between total phenolics with antioxidant and reducer power activities of the M. imbricata extracts (Table 1).

To demonstrate the antioxidant activity of extracts and bioactive compounds of $M$. imbricata, the free radical scavenging (FRS) using DPPH test was adopted. The levels of DPPH reduction proportionally induced by an antioxidant compound decrease the absorbance measured at $517 \mathrm{~nm}$. The dark red color of DPPH methanol solution rapidly disappears during reaction of the radical with compounds that possess ability to uptake proton radicals (Wu et al., 2006; Blois, 1958; Rodríguez et al., 2008).

The ethanol extract of leaves (LEtE) show better weight yield $(34.86 \%)$ than ethyl acetate extract (LEAcE) $(10.86 \%)$. By the other side, LEAcE shows higher concentration of phenolic compounds. These facts demonstrate the influence of the extractor solvent in the chemical composition of the M. imbricata extracts and the phenolic compound constitution of each one, which influences the respective results of antioxidant activity.

In all concentrations tested, the FRS observed for LEAcE was statistically superior to the activity encountered for LEtE and LChE (Table 2). By comparison of the FRS of leaves extracts at $100 \mathrm{ppm}$ with the activity presented by standards and extracts was possible to verify that the results of LEAcE and LEtE were statistically superior of those produced by galic acid (GA) and BHA. In similar concentrations the extract LChE doesn't show FRS activity (Table 3 ).

The biggest activity presented by LEAcE can have been resulted by the presence of epicatechin, later isolated from this extract. The antioxidant activity of epicatechin was previously described (Agrawal, 1989), like as the activity of tannins, a polymeric phenols detected using $\mathrm{FeCl}_{3}$ test. The significant selectivity of ethyl acetate in relation to procyanidin compounds, which present high antioxidant activity (Jayaprakasha et al., 2001) is important for the studies of pharmacological effects of $M$. imbricata.

Although FRS was not observed in extracts gotten of leaves and branches using non polar solvents, it is not possible to conclude the absence of this activity (Kranl et al., 2005). Experiments adopted to verify antioxidant activity of non-polar extracts and compounds (Murcia et al., 2004) must be used to obtain real conclusions about the antioxidant activity of $M$. imbricata non polar constituents.

The results of FRS (DPPH) activity assays using $50,100,200$ and $300 \mathrm{ppm}$ of branches ethyl acetate extract (BEAcE) were superior to those presented by BHA (100 ppm) and minor of that one presented by GA (100 ppm). The linear regression curve of the data obtained from these experiments demonstrates an FRS enhancement tendency associated to BEAcE concentration (Figure 1). Similar results were observed in FRS assays using root hidroethanolic extract (REWE) when compared to BHA (100 ppm). The FRS activity of REWE was superior only in higher concentrations (200 and $300 \mathrm{ppm}$ ) (Table 4).

The reducer power (RP) observed for all $M$. imbricata extracts of leaves revealed direct correlation with the concentration, being greater in $300 \mathrm{ppm}$ (Table 2). In relation to FRS activity, LEAcE showed different results in comparison with the others extracts. The data obtained for LEAcE were statistically superior only in the assays using $50 \mathrm{ppm}$ of this extract. For LEAcE and LEtE in all concentrations (100, 200 and $300 \mathrm{ppm})$, RP wasn't detected with different statistical value significance (Table 2 ). The RP of LChE was only observed in the tests using 200 and $300 \mathrm{ppm}$ of extract, but the results were inferior to those detected for the other extracts. Observing the data of Table 5 is possible to verify that the reducer power of GA is superior to RP produced by LEAcE and LEtE extracts. The RP of BHA was superior to RP observed for LChE and inferior to those produced by LEAcE and LEtE. The extract LEAcE and LEtE showed similar reduced power when analyzed by Tukey test ( $5 \%)$.

The reducer power data obtained from branches 
ethyl acetate extract (BEAcE) and root ethanol water extract (REWE) were submitted to linear regression analysis. Although BEAcE had showed reducer power variations associated to its concentration used in assays, wasn't possible to establish some mathematical equation or a model to explain the results encountered. In comparison to GA, the RP presented by REWE only was superior when $300 \mathrm{ppm}$ of extract was tested. (Table 4). The LEAcE extract showed greater total phenolics content (Table 1) and also greater FRS (DPPH) and RP in comparison with other extracts (Table 2). These facts indicate the existence of some correlation between the presence of phenolic compounds with the FRS and RP activities. Both CTC and MPC in all concentrations tested shown FRS activity

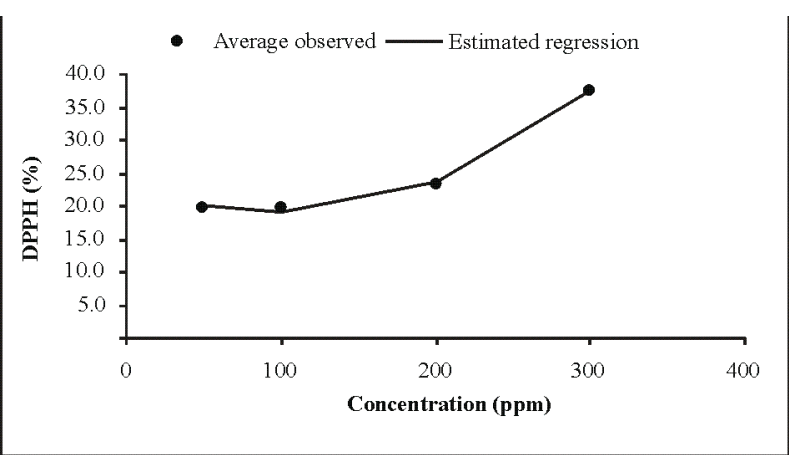

Figure 1. Free radical scavenging (FRS) (DPPH) capacity $(\hat{Y})$ showed by different concentrations of $M$. imbricata BEAcE extract.

$\hat{Y}=23,423568-0,088746 * c+0,000450 * c^{2} \quad R^{2}=98,21 \%$ $\mathrm{c}=$ concentration and $*$ Significant coefficient values at $5 \%$, by Tukey test.

Table 2. Free radical scavenging (FRS) (DPPH) and reducer power (RP) of the LEAcE, LEtE and LChE from M. imbricata.

\begin{tabular}{cccc}
\hline $\begin{array}{c}\text { Concentration } \\
(\mathrm{ppm})\end{array}$ & Extracts & FRS (DPPH) & RP \\
\hline 50 & LEAcE & $42.79^{\mathrm{a}}$ & $0.25^{\mathrm{a}}$ \\
& LEtE & $30.64^{\mathrm{b}}$ & $0.16^{\mathrm{b}}$ \\
& LChE & $0.00^{\mathrm{c}}$ & $0.00^{\mathrm{c}}$ \\
100 & LEAcE & $43.43^{\mathrm{a}}$ & $0.41^{\mathrm{a}}$ \\
& LEtE & $30.98^{\mathrm{b}}$ & $0.41^{\mathrm{a}}$ \\
& LChE & $0.00^{\mathrm{c}}$ & $0.01^{\mathrm{b}}$ \\
200 & LEAcE & $47.75^{\mathrm{a}}$ & $0.84^{\mathrm{a}}$ \\
& LEtE & $37.68^{\mathrm{b}}$ & $0.67^{\mathrm{a}}$ \\
& LChE & $7.38^{\mathrm{c}}$ & $0.04^{\mathrm{b}}$ \\
300 & LEAcE & $68.15^{\mathrm{a}}$ & $1.10^{\mathrm{a}}$ \\
& LEtE & $61.95^{\mathrm{b}}$ & $0.93^{\mathrm{a}}$ \\
& LChE & $13.39^{\mathrm{c}}$ & $0.10^{\mathrm{b}}$ \\
\hline
\end{tabular}

For each concentration, samples marked with the same letter don't shown statistical differences by Tukey test $(\mathrm{P}<0.05)$. superior to BHA (100 ppm) and GA (100 ppm) (Table 6 and 7).

Phenolic compounds represent one of the greater groups of bioactive compounds encountered in vegetable kingdom ( $\mathrm{Li}$ et al., 2006) and many of them shown antioxidant activity observed through different assays (Murcia et al., 2004; Kranl et al., 2005; Carvalho et al., 2008). Correlations between the antioxidant compound content in the material submitted to tests and the antioxidant activity are not easy to explain only using quantitative analyses (Capecka et al., 2005). In according to Skerget et al. (2005), sinergism between antioxidant compounds and others secondary metabolites produce differences in relation to the antioxidant efficacy of plant extracts.

Table 1. Percentage (g \%) of extracts and compounds isolated from M. imbricata and total phenolics content.

\begin{tabular}{lcc}
\hline Extract or compound & Yield $(\%)$ & Total phenolics $(\mathrm{mg} / \mathrm{g})$ \\
\hline LHE & 4.09 & nd \\
LHES & 1.95 & nd \\
LChE & 1.01 & nd \\
LEAcE & 10.86 & $659.27 \pm 31.68$ \\
LEtE & 34.86 & $440.89 \pm 66.82$ \\
DCT & 0.76 & nd \\
BHE & 1.61 & nd \\
BHES & 0.94 & nd \\
BEAcE & 2.01 & $85.79 \pm 3.07$ \\
MPC & 17.5 & $307.65 \pm 6.45$ \\
CTC & 17.7 & $1220.33 \pm 8.51$ \\
REWE & 7.28 & $422.57 \pm 15.89$ \\
\hline
\end{tabular}
nd = not detected; LHE $=$ Leave hexanic extract; LHES $=$ solid material from LHE; LEAcE = Leave ethyl acetate extract; LEtE $=$ Leave ethanolic extract; $\mathrm{BHE}=$ branches hexanic extract; BHES $=$ solid material from BHES; BEAcE $=$ branches ethyl acetate extract; $\mathrm{MPC}=$ mixture of phenolic compounds; $\mathrm{CTC}=$ epicatechin; REWE = roots hydro-alcoholic $(8: 2)$ extract.

Table 3. Comparison between the free radical scavenging (FRS) of M. imbricata extracts and standards (100 ppm) BHA and GA.

\begin{tabular}{cc}
\hline Material tested & FRS (DPPH) \\
\hline LEAcE & $43.43^{\mathrm{a}}$ \\
LetE & $30.98^{\mathrm{b}}$ \\
GA & $18.78^{\mathrm{c}}$ \\
BHA & $7.70 \mathrm{~d}$ \\
LChE & $0.00 \mathrm{e}$ \\
\hline
\end{tabular}

Media of triplicate result marked with the same letter doesn't shown statistical differences by Tukey test $(\mathrm{P}<0.05)$. LEAcE $=$ leave ethyl acetate extract, $\mathrm{LEtE}=$ leave ethanolic extract, $\mathrm{LChE}$ $=$ leave chloroform extract, $\mathrm{BHA}=$ butylhydroxyanisole and GA $=$ galic acid. 
Table 4. Free radical scavenging (FRS) (DPPH) and reducer power (RP) of $M$. imbricata root hydroethanolic extract (REWE).

\begin{tabular}{|c|c|c|c|c|c|c|}
\hline \multirow{2}{*}{ Material tested (ppm) } & \multirow{2}{*}{ FRS (DPPH) } & \multicolumn{2}{|c|}{ Variation $(\%)$} & \multirow{2}{*}{$\mathrm{RP}$} & \multicolumn{2}{|c|}{ Variation $(\%)$} \\
\hline & & BHA & GA & & BHA & GA \\
\hline BHA (100) & $7.70^{\mathrm{a}}$ & - & - & $0.33^{\mathrm{a}}$ & - & - \\
\hline GA $(100)$ & $18.78^{\mathrm{b}}$ & - & - & $0.63^{\mathrm{b}}$ & - & - \\
\hline REWE (50) & 19.73 & $156.12 *$ & $5.06^{\mathrm{n} . \mathrm{s}}$ & 0.13 & $-61.21 *$ & $-79.68 *$ \\
\hline$(100)$ & 19.76 & $156.56^{*}$ & $5.24^{\text {n.s }}$ & 0.23 & $-30.81^{\mathrm{n} . \mathrm{s}}$ & $-63.76^{*}$ \\
\hline$(200)$ & 23.20 & $201.13^{*}$ & $23.52 *$ & 0.42 & $26.26^{\text {n.s }}$ & $-33.86^{*}$ \\
\hline$(300)$ & 37.44 & $386.02 *$ & $99.36 *$ & 0.70 & $113.03 *$ & $11.59^{\mathrm{n} . \mathrm{s}}$ \\
\hline
\end{tabular}

In each term: ${ }^{a}$ differs from ${ }^{\mathrm{b}}$ by $\mathrm{F}$ test $(\mathrm{P}<0.05)$ and $*$ indicate that it is statistically different to the control, by Dunnett test $(\mathrm{P}<0.05)$. $\mathrm{BHA}=$ butylhydroxyanisole and $\mathrm{GA}=$ galic acid.

Table 5. Comparison between the reducer power (RP) of $M$. imbricata extracts and standards (100 ppm) BHA and GA.

\begin{tabular}{cl}
\hline Material tested & RP \\
\hline GA & $0.63^{\mathrm{a}}$ \\
LEAcE & $0.41^{\mathrm{b}}$ \\
LEtE & $0.41^{\mathrm{b}}$ \\
BHA & $0.33^{\mathrm{b}}$ \\
LChE & $0.01^{\mathrm{c}}$ \\
\hline
\end{tabular}

Media of triplicate, result marked with the same letter doesn't shown statistical differences by Tukey test $(\mathrm{P}<0.05)$. LEAcE $=$ leave ethyl acetate extract, $\mathrm{LEtE}=$ leave ethanolic extract, $\mathrm{LChE}=$ leave chloroform extract, $\mathrm{BHA}=$ butylhydroxyanisole and $\mathrm{GA}=$ galic acid.

Table 6. Free radical scavenging (FRS) and reducer power (RP) of epicatechin (CTC) from Maytenus imbricata.

\begin{tabular}{|c|c|c|c|c|c|c|}
\hline \multirow{2}{*}{ Material tested (ppm) } & \multirow{2}{*}{ FRS (DPPH) } & \multicolumn{2}{|c|}{ Variation $(\%)$} & \multirow{2}{*}{$\mathrm{RP}$} & \multicolumn{2}{|c|}{ Variation $(\%)$} \\
\hline & & BHA & GA & & BHA & GA \\
\hline BHA (100) & $7.70^{\mathrm{a}}$ & - & - & $0.33^{\mathrm{a}}$ & - & - \\
\hline GA (100) & $18.78^{b}$ & - & - & $0.63^{\mathrm{b}}$ & - & - \\
\hline CTC (50) & 31.39 & $307.53^{*}$ & $67.16^{*}$ & 0.43 & $30.00^{\text {n.s }}$ & $-31.90 *$ \\
\hline$(100)$ & 53.00 & $588.06^{*}$ & $182.23^{*}$ & 1.01 & $205.96^{*}$ & $60.26 *$ \\
\hline$(200)$ & 90.18 & $1070.71 *$ & $380.21 *$ & 1.12 & $239.19 *$ & $77.67 *$ \\
\hline$(300)$ & 92.35 & $1098.79 *$ & $391.73^{*}$ & 1.20 & $264.14^{*}$ & $90.74 *$ \\
\hline
\end{tabular}

In each term: ${ }^{a}$ differs from ${ }^{\mathrm{b}}$ by $\mathrm{F}$ test $(\mathrm{P}<0.05)$ and $*$ indicate that it is statistically different to the control, by Dunnett test $(\mathrm{P}<0.05)$. $\mathrm{BHA}=$ butylhydroxyanisole and $\mathrm{GA}=$ galic acid.

Table 7. Free radical scavenging (FRS) and reducer power (RP) of phenolic compounds mixture (MPC) from Maytenus imbricata.

\begin{tabular}{|c|c|c|c|c|c|c|}
\hline \multirow{2}{*}{ Material tested (ppm) } & \multirow{2}{*}{ FRS (DPPH) } & \multicolumn{2}{|c|}{ Variation $(\%)$} & \multirow{2}{*}{ PR } & \multicolumn{2}{|c|}{ Variation $(\%)$} \\
\hline & & BHA & $\mathrm{AcG}$ & & BHA & $\mathrm{AcG}$ \\
\hline BHA (100) & $7.70^{\mathrm{a}}$ & - & - & $0.33^{\mathrm{a}}$ & - & - \\
\hline GA (100) & $18.78^{\mathrm{b}}$ & - & - & $0.63^{\mathrm{b}}$ & - & - \\
\hline MPC (50) & 18.58 & $141.19 *$ & $-1.06^{\mathrm{n} . \mathrm{s}}$ & 0.16 & $-52.83^{*}$ & $-75.29 *$ \\
\hline$(100)$ & 18.64 & $141.97 *$ & $-0.75^{\mathrm{n} . \mathrm{s}}$ & 0.40 & $20.10^{\mathrm{ns} s}$ & $-37.09 *$ \\
\hline$(200)$ & 37.21 & $383.04 *$ & $98.148^{*}$ & 0.69 & $109.29 *$ & $9.63^{\text {n.s }}$ \\
\hline$(300)$ & 54.64 & $609.35 *$ & $190.97 *$ & 1.06 & $220.20 *$ & $67.72 *$ \\
\hline
\end{tabular}

In each term: ${ }^{\mathrm{a}}$ differs from ${ }^{\mathrm{b}}$ by $\mathrm{F}$ test $(\mathrm{P}<0.05)$ and $*$ indicate that it is statistically different to the control, by Dunnett test $(\mathrm{P}<0.05)$. $\mathrm{BHA}=$ butylhydroxyanisole and $\mathrm{GA}=$ galic acid. 


\section{CONCLUSION}

The results showed that leaves, branches and root extracts and a mixture of phenolic compounds (MPC) and epicatechin (CTC) isolated from M. imbricata (Celastraceae) have high total phenolic content and demonstrate a good free radical scavenging (FRS) and reducer power (RP) potential. Others studies objectiving the isolation and identification of new bioactive constituents from $M$. imbricata extracts, including in vivo antioxidant activity assays are important to explain the popular pharmacological activities attributes do this plant. It is the first time that totals phenolics content; free radical scavenging (DPPH) method and the reducer power activities are reported for $M$. imbricata.

\section{ACKNOWLEDGEMENTS}

The authors thank Dra. Rita Maria de CarvalhoOkano (UFV) for the botanical identification and Conselho Nacional de Desenvolvimento Científico e Tecnológico (CNPq) and Fundação de Apoio a Pesquisas do Estado de Minas Gerais (FAPEMIG) for financial support.

\section{REFERENCES}

Agrawal PK 1989. Carbon-13 NMR of Flavonoids. New York: Elsevier.

Allison AC, Cacabelos R, Lombardi VRM, Álvarez XA, Vigo C 2001. Celastrol, a potentantioxidantandanti-inflammatory drug, as a possible treatment for Alzheimer's disease. Prog Neuro-Psychop 25: 1341-1357.

Andrade CA, Costa CK, Bora K, Miguel MD, Miguel OG, Kerber VA 2007. Determinação do conteúdo fenólico e avaliação da atividade antioxidante de Acacia podalyriifolia A. Cunn. ex G. Don, Leguminosae-mimosoideae. Rev Bras Farmacogn 17: 231-235.

Avilla J, Teixidò A, Velasquèz C, Alvarenga N, Ferro E, Canela RJ 2000. Insecticidal activity of Maytenus species (Celastraceae) nortriterpene quinone methides against codling moth, Cydia pomonella (L.) (Lepidoptera: Tortricidae). J Agric Food Chem 48: 88-92.

Balestrin L, Dias JFG, Miguel OG, Dall'Stella DSG, Miguel MD 2008. Contribuição ao estudo fitoquímico de Dorstenia multiformis Miquel (Moraceae) com abordagem em atividade antioxidante. Rev Bras Farmacogn 18: 230235.

Blois MSK 1958. Antioxidant determination by the use of a stable free radical. Nature 4617: 1199-1120.

Capecka E, Mareczek A, Leja M 2005. Antioxidant activity of fresh and dry herbs of some Lamiaceae species. Food Chem 93: 223-226.

Carvalho CA, Silva MB, Oliveira TG, Lima JM, Rosa MB 2008. Estudo espectrométrico de diferentes estágios fenológicos da Brassica oleracea var. capitata. Rev Bras Farmacogn 18: 249-257.

Castilhos TS, Giordani RB, Henriques AT, Menezes FS, Zuanazzi JAS 2007. Avaliação in vitro das atividades antiinflamatória, antioxidante e antimicrobiana do alcalóide montanina. Rev Bras Farmacogn 17: 209-214.

El Tahir A, Satti GMH, Khalid S A 1999. Antiplasmodial activity of selected sudanese medicinal plants with emphasis on Maytenus senegalensis (Lam.) Exell. J Ethnopharmacol 64: 227-233.

Estevam CS, Cavalcanti AM, Cambui EVF, Araújo Neto V, Leopoldo PTG, Fernandes RPM, Araujo BS, Porfírio Z, Sant'Ana AEG 2009. Perfil fitoquímico e ensaio microbiológico dos extratos da entrecasca de Maytenus rigida Mart. (Celastraceae). Rev Bras Farmacogn 19: 299-303.

Fonseca AM, Bizerra AMC, Souza JSN, Monte FJQ, Oliveira MCF, Mattos MC, Cordel GA, Braz-Filho R, Lemos TLG 2009. Constituents and antioxidant activity of two varieties of coconut water (Cocos nucifera L.). Rev Bras Farmacogn 19: 193-198.

Gonzalez FG, Portela TY, Stipp EJ, Di Stasi LC 2001. Antiulcerogenic and analgesic effects of Maytenus aquifolium, Sorocea bomplandii and Zolernia ilicifolia. J Ethnophamacol 77: 41-47.

Harbone JB 1994. The Flavonoids Advances in Research since 1986. London: Chapman \& Hall.

Harish R, Shivanandappa T 2006. Antioxidant activity and hepatoprotective potential of Phyllanthus niruri. Food Chem 95: 180-185.

Iha SM, Migliato KF, Vellosa JCR, Sacramento LVS, Pietro RCLR, Isaac VLB, Brunetti IL, Corrêa MA, Salgado HRN 2008. Estudo fitoquímico de goiaba (Psidium guajava L.) com potencial antioxidante para o desenvolvimento de formulação fitocosmética. Rev Bras Farmacogn 18: 387-393.

Jayaprakasha GK, Singh RP, Sakariah KK 2001. Antioxidant activity of grape seed (Vitis vinifera) extracts on peroxidation models in vitro. Food Chem 73: 285-290.

Jorge RM, Leite JPV, Oliveira AB, Tagliati CA 2004. Evaluation of antinociceptive, anti-inflamatory and antiulcerogenic activities of Maytenus ilicifolia. J Ethnopharmacol 94: 93-100.

Kranl K, Schlesier K, Bitsch R, Hermann H, Rohe M, Böhm V 2005. Comparing antioxidative food additives and secondary plant products-use of different assays Food Chem 93: 171-175.

Krishnamoorthy G, Chellappan DR, Joseph J, Ravindhran D, Shabi MM, Uthrapathy S, Rajamanickam VG, Dubey GP 2009. Antioxidant activity of Nelumbo nucifera (Gaertn) flowers in isolated perfused rat kidney. Rev Bras Farmacogn 19: 224-229.

Li Y, Guo C, Yang J, Wei J, Xu J, Cheng S 2006. Evaluation of antioxidant properties of pomegranate peel extract in comparison with pomegranate pulp extract. Food Chem 96: 254-260.

Montanari T, Carvalho JE, Dolder H 1998. Effect of Maytenus ilicifolia Mart. ex. Reiss on Spermatogenesis. Contraception 57: 335-339.

Morais SM, Cavalcanti ESB, Costa SMO, Aguiar LA 2009. Ação antioxidante de chás e condimentos de grande consumo no Brasil. Rev Bras Farmacogn 19: 315-320.

Mota KSL, Pita JCLR, Estevam EC, Medeiros VM, Tavares JF, Agra MF, Diniz MFFM, Silva MS, Batista LM 2008. Evaluation of the toxicity and antiulcerogenic activity of the ethanol extract of Maytenus obtusifolia Mart. Leaves. Rev Bras Farmacogn 18: 441-446.

Murcia MA, Egea I, Romojaro F, Parras P, Jimenez AM, 
Martinez-Tome M 2004. Antioxidant evaluation in dessert Spices compared with common food additives: Influence of irradiation procedure. J Agric Food Chem 52: $1872-1881$

Nunes XP, Mesquita RF, Silva DA, Lira DP, Costa VCO, Silva MVB, Xavier AL, Diniz MFFM, Agra MF 2008. Constituintes químicos, avaliação das atividades citotóxica e antioxidante de Mimosa paraibana Barneby (Mimosaceae). Rev Bras Farmacogn 18 (Supl): 718723.

Okano, RMC 1992. Estudos Taxonômicos do gênero Maytenus Mol. Emend. Mol. (Celastraceae) do Brazil extraamazônico. Campinas, 253p. Tese de Doutorado, Universidade Estadual de Campinas.

Okine LKN, Nyarko AK, Osei-Kwabena N, Oppong IV, Barnes F, Ofosuhene M 2005. The antidiabetic activity of herbal preparation ADD-199 in mice: a comparative study with two oral hypoglycaemic drugs. J Ethnopharmacol 97: 31-38.

Orabi KY, Al-Qasoumi SI, El-Olemy MM, Mossa JS, Muhammad I 2001. Dihydroagarofuran alkaloid and triterpenes from Maytenus heterophylla and Maytenus arbutifolia. Phytochemistry 58: 475-480.

Pullen CB, Schmitz P, Hoffmann D, Meurer K, Boettcher T, Bamberg DV, Pereira AM, França, SC, Hauser M, Geertsema H, Wyk AV, Mahameed T, Floss HG, Leistner E 2003. Occurrence and no-detectability of maytansinoids in individual plants of the genera Maytenus and Putterlickia. Phytochemistry 62: 377-387.

Queiroga CL, Silva GF, Dias PC, Possenti A, Carvalho JE 2000. Evaluation of antiulcerogenic activity of friedelan$3 \beta-o l$ and friedelin isolated from Maytenus ilicifolia (Celastraceae). J Ethnopharmacol 72: 465-468.

Quintans-Júnior LJ, Almeida JRGS, Lima JT, Nunes XP, Siqueira JS, Oliveira LEG, Almeida RN, Athayde-Filho PF, Barbosa-Filho JM 2008. Plants with anticonvulsant properties - a review. Rev Bras Farmacogn 18 (Supl.): 798-819.

Ravelo AG, Braun AE, Orellana HC, Sacau EP, Siverio DM 2004. Recent studies on natural products as anticancer agents. Curr Top Med Chem 4: 241-265.

Rebelo MM, Silva JKR, Andrade EHA, Maia JGS 2009. Antioxidant capacity and biological activity of essential oil and methanol extract of Hyptis crenata Pohl ex Benth. Rev Bras Farmacogn 19: 230-235.

Rodríguez M, Hasegawa M, González-Mújica F, Motta N, Castillo A, Castillo J, Zea E, Mora K, Sousa L, González A, Camejo D 2008. Antidiabetic and antiradical activities of plants from Venezuelan Amazon. Rev Bras Farmacogn 18: 331-338.

Santos SC, Mello JCP 2003. Taninos. In: Simões, C.M.O., Schenkel, E.P., Gosmann G., Mello J.C.P., Mentz L.A., Petrovick P.R. (org.) Farmacognosia da Planta ao Medicamento. 5.ed. Florianópolis: Editora da UFRGS, p.615-656.

Santos VL, Costa VBM, Agra MF, Silva BA, Batista LM 2007. Pharmacological studies of ethanolic extracts of Maytenus rigida Mart (Celastraceae) in animal models. Rev Bras Farmacogn 17: 336-342.

Silva SRS, Silva GDF, Barbosa LC, Duarte LP, Vieira Filho SA 2005. Lupane pentacyclic triterpenes isolated from stems and branches of Maytenus imbricata (Celastraceae). Helv Chim Acta 88: 1102-1109.
Singh RP, Chidambara KNM, Jayaprakasha GK 2002. Studies on the antioxidant activity of Pormegranate (Punica granatum) peel and seed extracts using in vitro models. $J$ Agric Food Chem 50: 81-86

Skerget M, Kotnik P, Hadolin M, Hras AR, Simonic M, Knez Z 2005. Phenols, proanthocyanidinis, flavones and flavonols in some plant materials and their antioxidant activities. Food Chem 89: 191-198.

Sousa DP, Almeida RN 2005. Neuroleptic-like properties of the chloroform extract of Maytenus obtusifolia Mart. Roots. Biol Pharm Bull 2: 224-225.

Sousa JR, Silva GDF, Pedersoli JL, Alves RJ 1990. Friedelane and oleanane triterpenoids from bark wood of Austroplenckia populnea. Phytochemistry 29: 3259-3261.

Souza TJT, Apel MA, Bordignon S, Matzenbacher NI, Zuanazzi JAS, Henriques AT 2007. Composição química e atividade antioxidante do óleo volátil de Eupatorium polystachyum DC. Rev Bras Farmacogn 17: 368-372.

Spivey AC, Weston M, Woodhead S 2002. Celastraceae sesquiterpenoids: biological activity and synthesis. Chem Soc Rev 31: 43-59.

Vicentino ARR, Menezes FS 2007. Atividade antioxidante de tinturas vegetais, vendidas em farmácias com manipulação e indicadas para diversos tipos de doenças pela metodologia do DPPH. Rev Bras Farmacogn 17: 384-387.

Wu C, Chen F, Wang X, Kim HJ, He G, Zitlin VH, Huang G 2006. Antioxidant constituents in feverfew (Tanacetum parthenium) extract and their chromatographic quantification. Food Chem 96: 220-227.

Yildrin A, Mavi A, Kara AA 2001. Determination of antioxidant and antimicrobial activities of Rumex crispus L. extracts. J Agric Food Chem 49: 4083-4089. 